\title{
Deconstructing 'the foreign': The limits of citizenship for explaining price competition in the Spaza sector in South Africa
}

\author{
Laurence Piper $^{\mathrm{a}}$ and Derek $\mathrm{Yu}^{\mathrm{b}}$

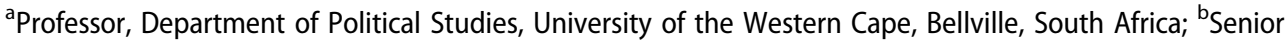 \\ Lecturer, Department of Economics, University of the Western Cape, Bellville, South Africa
}

\begin{abstract}
An important component of the informal economy in South Africa, the Spaza sector is portrayed as dominated by foreign nationals who outcompete South African shopkeepers on price. Indeed, this business competition from foreign nationals is a key reason given to explain xenophobia in South Africa. This article sets out to interrogate this widely held assumption. Drawing on evidence from over 1000 Spaza shops from South Africa's three main cities, the article makes the case that business competitiveness does not correspond with 'foreign' or South African identities in a simple way. Firstly, while citizenship or nationality is a factor, it is not captured by the labels of 'foreign' versus South African, as there are significant differences by nationality within the 'foreign'. Secondly, not all foreign nationalities out-compete South Africans on price. Thirdly, place matters too, not only because we find different nationalities in different cities, but also because there are different patterns of price competition by nationality in each place. Lastly, there are product-specific dynamics that impact on price more profoundly than nationality. For example, regardless of nationality, milk is cheaper in Cape Town and bread is cheaper in Johannesburg.
\end{abstract}

\author{
KEYWORDS \\ Xenophobia; refugee; \\ informal economy; retail; \\ price; competition \\ JEL CODE \\ $\mathrm{J} 00$
}

\section{Introduction}

The informal economy in South Africa has been enjoying increasing recognition in recent times, although it is less significant than for most other economies in the region and in Africa (ILO, 2009). In general, informal-sector employment is characterised by inferior earnings, weak job security, insufficient fringe benefits (e.g. lack of entitlement to medical aid and paid leave) and significant under-employment (Blunch et al., 2001; Essop \& Yu, 2008a; Henley et al., 2009) compared with formal-sector employment. Nonetheless, some participants in the labour force still opt to work in the informal sector: some prefer to operate their businesses informally to avoid the rigid labour market regulations and taxation they would face if they operated the enterprises formally, or some (particularly women) prefer to work flexible hours so as to balance income-raising activities and 
Table 1: Informal-sector contribution to South Africa's total employment.

\begin{tabular}{lccc}
\hline Year & $\begin{array}{c}\text { Informal-sector } \\
\text { employment }\end{array}$ & $\begin{array}{c}\text { Total } \\
\text { employment }\end{array}$ & $\begin{array}{c}\text { Informal-sector employment as \% of total } \\
\text { employment }\end{array}$ \\
\hline 2006 & 2849035 & 12787285 & 22.3 \\
2007 & 2452111 & 13293327 & 18.4 \\
2008 & 2398018 & 14561398 & 16.5 \\
2009 & 2188124 & 13841980 & 15.8 \\
2010 & 2370549 & 13668819 & 17.3 \\
2011 & 2350859 & 14131609 & 16.6 \\
2012 & 2420190 & 14583192 & 16.6 \\
2013 & 2444735 & 15061904 & 16.2 \\
2014 & 2514784 & 15146354 & 16.6 \\
2015 & 2777657 & 15676015 & 17.7 \\
\hline
\end{tabular}

Source: Authors' own calculations using Labour Force Survey 2006-07 and Quarterly Labour Force Survey 2008-15 data.

home responsibilities (Kershoff, 1996; Anderson, 1998; Kingdon \& Knight, 2004; Palmade \& Anayiotos, 2005; Perry et al., 2007). In contrast, some people reluctantly engage in informal-sector activities either because they have been retrenched from the formal sector (e.g. due to economic recession) or because they simply struggle to find work in the formal sector due to their low human capital (Fields, 1975; Bernabé, 2002).

While notoriously difficult to measure in terms of gross domestic product, employment data offer a more reliable insight into this sector. In the 1997-99 October Household Surveys and 2000-07 Labour Force Surveys, informal-sector employment was derived by Statistics South Africa purely from the respondents' self-perceived enterprise registration status. That is, if they declared the business was not registered, they were defined as informal-sector workers. This methodology was applied to both employees and the self-employed. With the introduction of the Quarterly Labour Force Survey in 2008 this approach was revised because many employees may not clearly know whether the enterprise they work for is registered or not. Instead, if the employee declares that income tax is deducted by his/her employer and there are fewer than five employees in the enterprise, then he/she is identified as an informal-sector worker. For the selfemployed the pre-existing methodology remains in use, but instead of the self-perception question, the respondents' answers on income tax and VAT registration are rather used to distinguish informal workers (Essop \& Yu, 2008b:8).

As demonstrated in Table 1, the informal economy has contributed on average about 2.5 million jobs in the last decade. This accounts for between 15 and $20 \%$ of jobs in the country. As confirmed by recent research by the Sustainable Livelihoods Foundation, an important form of informal micro-enterprise throughout poor, black urban settlements of the country is the local grocery store, colloquially known as the Spaza shop (SLF, 2011). Second only in number to shebeens, or drinking establishments, in terms of frequency in these areas, Spaza shops contribute to approximately $4 \%$ of employment in the informal sector, or about 100000 jobs. ${ }^{1}$ Notably, more than $80 \%$ of Spaza jobs take place in the informal sector (Table 2).

In addition to being an important component of the informal economy, Spaza shops matter for our purposes in this article because they are often run by foreign nationals, and these foreign shopkeepers have often been the subjects of xenophobic

\footnotetext{
1Essop \& Yu (2008a) found that 'Spaza shop operator' has always been ranked as one of the top five detailed occupational categories of informal-sector employment.
} 
Table 2: Spaza shop employment (including owners and operators) in South Africa.

\begin{tabular}{lccc}
\hline Year & $\begin{array}{c}\text { Spaza shop } \\
\text { employment }\end{array}$ & $\begin{array}{c}\text { \% of Spaza shop employment } \\
\text { taking place in informal sector }\end{array}$ & $\begin{array}{c}\text { Informal sector Spaza shop employment as \% } \\
\text { of total informal sector employment }\end{array}$ \\
\hline 2006 & 124761 & 90.2 & 3.9 \\
2007 & 105999 & 87.9 & 3.8 \\
2008 & 93432 & 80.2 & 3.1 \\
2009 & 112861 & 84.1 & 4.3 \\
2010 & 99687 & 91.8 & 3.9 \\
2011 & 104871 & 90.7 & 4.0 \\
2012 & 98555 & 91.6 & 3.7 \\
2013 & 91301 & 87.8 & 3.3 \\
2014 & 95044 & 94.7 & 3.6 \\
2015 & 110499 & 89.7 & 3.6 \\
\hline
\end{tabular}

Source: Authors' own calculations using Labour Force Survey 2006-07 and Quarterly Labour Force Survey 2008-15 data.

attacks. ${ }^{2}$ Indeed, the last 10 years have seen growing public awareness about violent attacks against foreign shopkeepers in South Africa, especially those who run Spaza shops. The popular discourse that justifies these attacks alleges that foreigners are taking away jobs, state grants and other social opportunities that rightly belong to South African only. For example, in reporting large-scale attacks on more than 100 small businesses in Port Elizabeth in 2013, the Global Post (2013) reported that "many people accuse "foreigners" of taking their jobs, or of putting South African shopkeepers out of business by undercutting their prices'. Similarly, the Somaliland Press (2012) reported that mobs tell Somalis to leave South Africa in part because they 'fear that they will take their jobs, townships, businesses and eventually their country'.

Claims that foreigners are illegitimate competitors for scarce resources are made frequently all around the world, and are evident currently in the United Kingdom with the rise of the UK Independence Party. Other examples abound, including Belgium (Zagefka et al., 2007), Israel (Pedahzur \& Yishai, 1999; Semyonov et al., 2002), Germany (Wimmer, 1997), Turkey (Zagefka et al., 2007), the United States (Citrin et al., 1997) as well as South Africa (Crush, 2008; Everett, 2011). In the South African literature, a related debate has ensued in respect of the Spaza sector where foreign shopkeepers are said to dominate the sector at the expense of South African shopkeepers. Indeed, it is widely accepted that foreign Spaza shopkeepers have impacted on the local informal economy of the urban township and informal settlements both in the increasing number of foreign run shops in the last 10 years, but also by competition with South African shopkeepers on price (Africa Unite, 2007; Department of the Premier, 2007). Hence, a number of studies (e.g. Charman et al., 2012; Gastrow \& Amit, 2013) have identified competition on price as a central reason for the rise of the Somali Spaza owner in the Cape, and the decline of South African run shops. Some have even attributed the attacks on foreign Spaza shops as a response to this alleged reality, although there is a complex debate on this question (see Charman \& Piper, 2012).

The advent of competition on price in the Spaza sector is important economically because this is not a practice historically embraced by South African township traders (Charman \& Petersen, 2007), whose motivations for trading are not necessarily 'reducible to the idea of "maximisation of profit"' (Neves \& Du Toit, 2012:131). As already noted, this

\footnotetext{
${ }^{2}$ Please note that we define 'citizenship' as per international law as the status assigned to someone under law as being a member of a state. In this article it could be used interchangeably with 'nationality' (Weis, 1979:3).
} 
development is important politically in that it forms a point of potential social conflict that can be used to justify xenophobic attacks. Consequently, in what follows this article takes great care to interrogate carefully and systematically, and in ways well supported by evidence, claims about price competition and identity in the Spaza sector in South Africa.

What emerges from our analysis is a picture very different from popular discourse about 'foreigners outcompeting locals on price' for several reasons. First, the national identity of the Spaza shopkeeper changes significantly by place across South Africa. Second, the notion that the 'foreign' shopkeeper outcompetes the South African shopkeeper is an overstatement of the reasons for price variation. If one compares Spaza shops on stock and price across the whole sample, then South Africans are actually a little cheaper on average than Mozambicans and Zimbabweans, although more expensive than Bangladeshi and Somali shopkeepers. Further, even though there is evidence that many foreigners do outcompete South African shopkeepers on price at the level of the city, the differences are generally small, and as large between different foreign nationalities as between all foreigners and South Africans. Third, variables other than national identity correlate more strongly with price differences such as the spatial location of shops and the particular product in question. Thus, all loaves of bread are cheaper in Gauteng than Cape Town, for example, and one cannot even by Double $\mathrm{O}$ cool drink in Gauteng. This suggests placespecific supply chain dynamics. In short, the assumption that the 'foreign:South Africa' contrast captures the dynamics of price competition in the Spaza sector in South Africa is inaccurate and misleading.

\section{Methodology}

The data used in this study come from surveys conducted with 1051 Spaza shopkeepers nationwide. More specifically, the data come from eight local-area censuses conducted in townships and informal settlements in Cape Town (575 Spaza shops in total), Gauteng (350 in total) and Durban (126 in total) by the Sustainable Livelihoods Foundation (SLF) from 2011 to 2013 (SLF, 2014). More specifically, data were collected from December 2010 to May 2011 in Delft South; in 2011 in Imizamo Yethu, Overcome Heights, Phillipi, Seawinds, Sweet Home Farm, Vryground and Capricorn; in 2012 in Ivory Park and Tembisa; and in 2013 in KwaMashu. All prices and calculations that follow are in constant 2013 prices, so as to control for the impact of inflation. At each site a team spatially geo-located every identifiable business on each street, and conducted surveys with the traders from each of the main business types, including Spaza shops. For more on this methodology, see Charman et al. (2015).

If one examines Table 3, it is clear that Ivory Park accounts for the highest share of the overall sample (20.7\%), followed by Delft South (17.1\%) and Phillipi (16.0\%). Vryground accounts for the lowest share (0.2\%), followed by Overcome Heights (2.1\%) and Seawinds (3.1\%). Looking at the South Africans only, it is interesting that Ivory Park no longer accounts for the largest share, but rather KwaMashu $(22.0 \%)$, followed by Phillipi (20.4\%) and Delft South (17.8\%). In contrast, looking at the foreigners only, the Ivory Park share is the highest (27.0\%), followed by Delft South (16.5\%) and Tembisa (15.3\%). In terms of rows, it is notable that the South African share is clearly dominant in KwaMashu (88.9\%), Sweet Home Farm (79.1\%) and Phillipi (61.9\%). However, the foreign share is more dominant in Vryground (100.0\%, but keep in mind that there are 
Table 3: Location of Spaza shops in the sample.

\begin{tabular}{|c|c|c|c|c|c|c|c|c|c|c|}
\hline \multirow{2}{*}{\multicolumn{2}{|c|}{ Location }} & \multicolumn{3}{|c|}{ Number } & \multicolumn{3}{|c|}{ Row total (\%) } & \multicolumn{3}{|c|}{ Column total (\%) } \\
\hline & & \multirow{2}{*}{$\begin{array}{l}\text { South } \\
\text { African } \\
14\end{array}$} & \multirow{2}{*}{$\begin{array}{l}\text { Foreign } \\
53\end{array}$} & \multirow{2}{*}{$\begin{array}{l}\text { Total } \\
67\end{array}$} & \multirow{2}{*}{$\begin{array}{c}\begin{array}{c}\text { South } \\
\text { African }\end{array} \\
20.9\end{array}$} & \multirow{2}{*}{$\begin{array}{c}\text { Foreign } \\
79.1\end{array}$} & \multirow{2}{*}{$\begin{array}{l}\text { Total } \\
100.0\end{array}$} & \multirow{2}{*}{$\begin{array}{c}\begin{array}{c}\text { South } \\
\text { African }\end{array} \\
2.7\end{array}$} & \multirow{2}{*}{$\begin{array}{c}\text { Foreign } \\
9.8\end{array}$} & \multirow{2}{*}{$\begin{array}{l}\text { Total } \\
6.4\end{array}$} \\
\hline Cape & Capricorn & & & & & & & & & \\
\hline \multirow[t]{7}{*}{ Town } & Delft South & 91 & 89 & 180 & 50.6 & 49.4 & 100.0 & 17.8 & 16.5 & 17.1 \\
\hline & $\begin{array}{l}\text { Imizamo } \\
\text { Yethu }\end{array}$ & 7 & 53 & 60 & 11.7 & 88.3 & 100.0 & 1.4 & 9.8 & 5.7 \\
\hline & $\begin{array}{c}\text { Overcome } \\
\text { Heights }\end{array}$ & 9 & 13 & 22 & 40.9 & 59.1 & 100.0 & 1.8 & 2.4 & 2.1 \\
\hline & Phillipi & 104 & 64 & 168 & 61.9 & 38.1 & 100.0 & 20.4 & 11.8 & 16.0 \\
\hline & Seawinds & 18 & 15 & 33 & 54.5 & 45.5 & 100.0 & 3.5 & 2.8 & 3.1 \\
\hline & $\begin{array}{l}\text { Sweet Home } \\
\text { Farm }\end{array}$ & 34 & 9 & 43 & 79.1 & 20.9 & 100.0 & 6.7 & 1.7 & 4.1 \\
\hline & Vryground & 0 & 2 & 2 & 0.0 & 100.0 & 100.0 & 0.0 & 0.4 & 0.2 \\
\hline Durban & KwaMashu & 112 & 14 & 126 & 88.9 & 11.1 & 100.0 & 22.0 & 2.6 & 12.0 \\
\hline \multirow[t]{2}{*}{ Gauteng } & Ivory Park & 72 & 146 & 218 & 33.0 & 67.0 & 100.0 & 14.1 & 27.0 & 20.7 \\
\hline & Tembisa & 49 & 83 & 132 & 37.1 & 62.9 & 100.0 & 9.6 & 15.3 & 12.6 \\
\hline All & & 510 & 541 & 1051 & 48.5 & 51.5 & 100.0 & 100.0 & 100.0 & 100.0 \\
\hline
\end{tabular}

only two respondents in total in this location), Imizamo Yethu (88.3\%), Capricorn (79.1\%) and Ivory Park (67.0\%).

Notably, while the data for each site are census data, and therefore are fully representative for the site, the collation across the eight sites does not constitute a representative national sample. Thus while the sheer size and spatial spread of the sample is suggestive, as are the recurring spatial patterns in respect of business types (e.g. Spaza shops are always evenly spread across a settlement), it is not a basis from which to generalise statistically to the rest of the country. Hence, while we can have near absolute levels of confidence in the claims with respect to each site, we cannot have the same confidence when speaking of the country as a whole.

The key data used in this article are not the spatial data but rather the data collected from interviews with 1051 shopkeepers across the eight sites. These interviews sourced prices of key products, amongst other things. In terms of prices we asked each shopkeepers the price of the 12 most common products, namely: 1 litre milk, 6 eggs, half loaf of white bread, full loaf of white bread, $250 \mathrm{~g}$ sugar, $500 \mathrm{~g}$ sugar, $340 \mathrm{ml}$ Coke, 1.5 litre Coke, Jive, Double $\mathrm{O}$, premium cigarettes, economic cigarettes. These data form the basis of a price comparison across site, by nationality and by product, which allows us to interrogate the popular claim that foreign shopkeepers are more price competitive than South Africans.

\section{Unpacking Spaza competitiveness}

In what follows the article unpacks the sample of shopkeepers spatially and by nationality, demonstrating both that South Africans constitute the single largest nationality in the sample and that very different nationalities are found in each of the three cities. Second, the article examines the extent of stock found in Spazas by nationality, demonstrating that some nationalities (Zimbabweans and Mozambicans) hold less stock than South Africans, suggesting fewer resources, while others hold more. Further, the article compares the average price of products, demonstrating that, for a basket of the top 12 goods, Somalis and Bangladeshi shopkeepers are the cheapest, but that Zimbabweans and Mozambicans are more expensive than South Africans. Third, the article examines 
prices at the level of the three main cities, which reveals that in each location, foreign shopkeepers are often cheaper than South Africans, but usually only slightly. Lastly, if we look at prices by product, it is clear that nationality has less of an impact than in which city the product is sold.

\subsection{Nationality and spatiality}

To begin with the nationality of shopkeepers, Figure 1 demonstrates that 510 of the 1051 respondents, or $48.5 \%$, are South Africans, and the remaining 541 or $51.5 \%$ are foreigners. Taken as a whole then, the sample is divided roughly 50:50, South African to foreign, but actually there are more than double the number of South Africans shopkeepers than the 236 Somali shopkeepers, who constitute the second most common nationality. Furthermore, as revealed in Figure 2, when unpacked spatially, the distribution of nationalities varies tremendously by city such that 220 of the 236 Somali shopkeepers, 93\%, are found in Cape Town, 103 of 149 Ethiopian shopkeepers, or 70\%, are in Gauteng, as were 38 of a total of 46 , or $83 \%$, of Bangladeshi shopkeepers. The identity of 'foreign' shopkeepers therefore differs quite profoundly from place to place, and is of little use in identifying the actual nationalities involved in any city.

\subsection{Spaza stock}

While Spaza shops stock a wide variety of goods, we identified the 12 most common products from our survey. Moreover, if one analyses the extent to which shopkeepers have these 12 items in their shops, and break this down by nationality as presented in

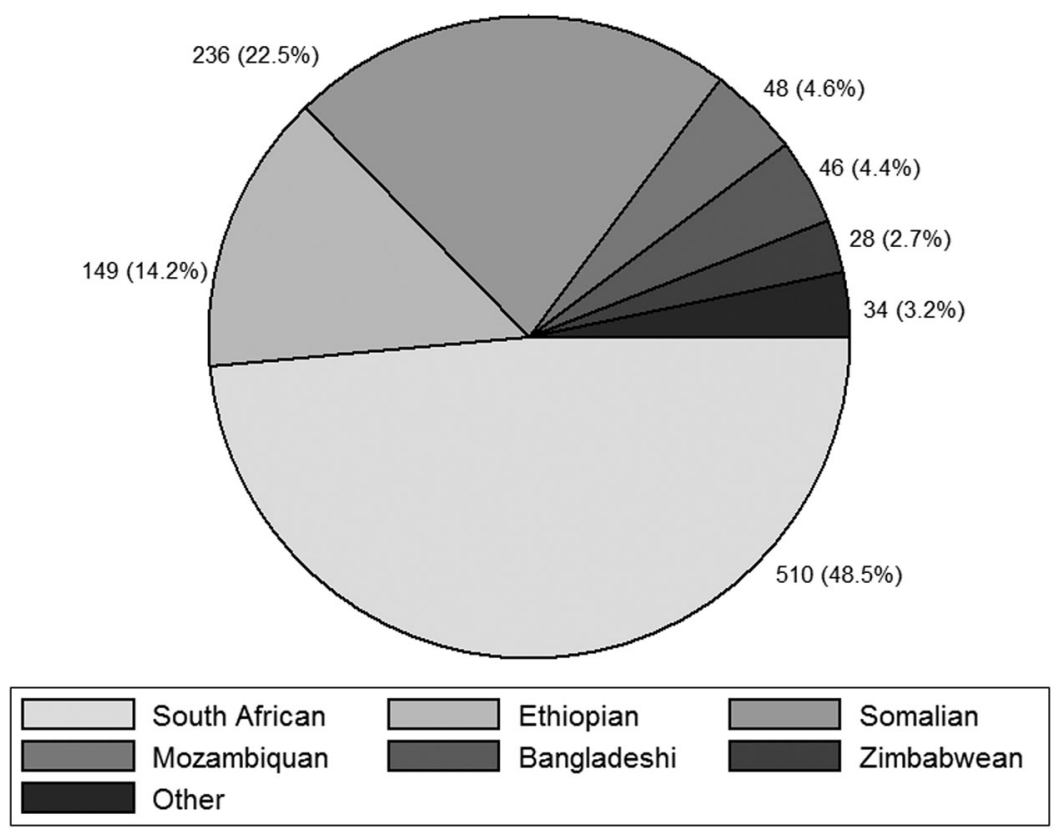

Figure 1: Nationality of Spaza shopkeepers in the sample. 


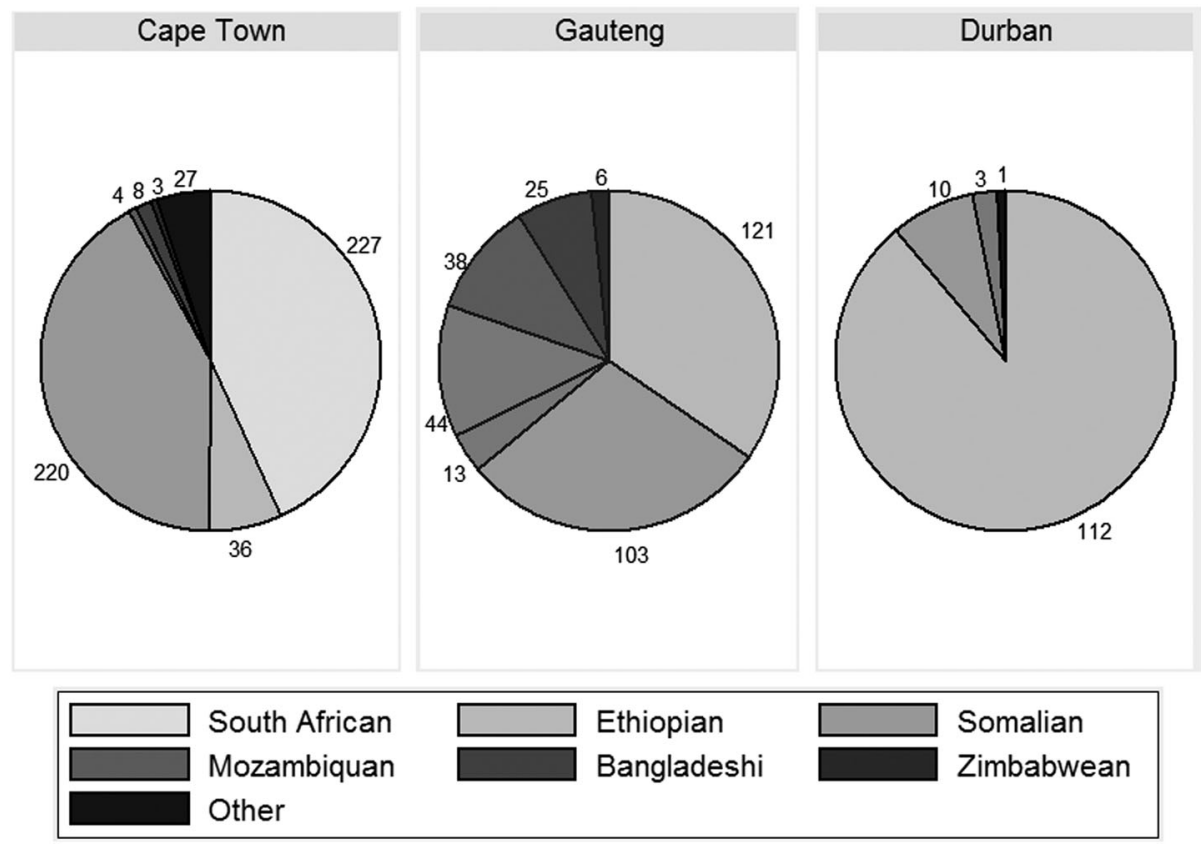

Figure 2: Nationality of Spaza shopkeepers by the three cities.

Table 4, then once again the South African versus foreign contrast quickly breaks down. We find that South Africans are more likely to have certain items in stock than some nationalities. For example, they are more likely to have a half loaf of white bread on their shelves than most. Conversely, Somalis and Ethiopians are more likely to stock sugar than most other nationalities, and Mozambicans and Bangladeshis almost always have eggs in their stores. Further, if one treats the 12 products as a basket of goods with each item carrying the same weight, ${ }^{3}$ then South Africans generally have larger stock than Zimbabwean and Mozambicans shopkeepers, although less than other nationalities. Notable also is that it is really just the Somali and Bangladeshi - and perhaps the Ethiopian - shopkeepers who have significantly more on the shelves than other nationalities.

\subsection{Price and location}

Before comparing the price differences (if any) by nationality, it is important to find out whether significant price differences already exist by location of the Spaza shops. It can be observed from Table 5 that the mean prices are cheaper in Cape Town. In particular, it is interesting that the mean prices of eight products are significantly cheaper in Cape Town when compared with Durban and Gauteng respectively. Such difference is the greatest for 1 litre milk (approximately R5 cheaper on average in the Cape Town Spaza shops). On other hand, when comparing Durban and Gauteng, the mean prices of six products are

\footnotetext{
${ }^{3}$ Because the sales data are not collected in the survey, throughout this study, we assume an equal 'weight' of each of the 12 products in the 'consumption basket' when deriving the average estimate.
} 
Table 4: Number and proportion of shopkeepers reporting stock by nationality and product.

\begin{tabular}{|c|c|c|c|c|c|c|c|c|}
\hline & & & & & Foreign & & & \\
\hline & $\begin{array}{c}\text { South African } \\
(n=510)\end{array}$ & $\begin{array}{l}\text { Ethiopian } \\
(n=149)\end{array}$ & $\begin{array}{l}\text { Somalian } \\
(n=236)\end{array}$ & $\begin{array}{l}\text { Mozambiquan } \\
\quad(n=48)\end{array}$ & $\begin{array}{l}\text { Bangladeshi } \\
\quad(n=46)\end{array}$ & $\begin{array}{c}\text { Zimbabwean } \\
\quad(\mathbf{n}=\mathbf{2 8})\end{array}$ & $\begin{array}{c}\text { Other } \\
(n=34)\end{array}$ & $\begin{array}{l}\text { Foreign total } \\
(n=541)\end{array}$ \\
\hline 1 litre milk & 284 & 90 & 208 & 12 & 32 & 9 & 20 & 371 \\
\hline & $55.7 \%$ & $60.4 \%$ & $88.1 \%$ & $25.0 \%$ & $69.6 \%$ & $32.1 \%$ & $58.8 \%$ & $68.6 \%$ \\
\hline 6 eggs & 426 & 140 & 222 & 47 & 45 & 25 & 23 & 502 \\
\hline & $83.5 \%$ & $94.0 \%$ & $94.1 \%$ & $97.9 \%$ & $97.8 \%$ & $89.3 \%$ & $67.6 \%$ & $92.8 \%$ \\
\hline Half loaf of white bread & 260 & 44 & 169 & 19 & 19 & 7 & 18 & 276 \\
\hline & $51.0 \%$ & $29.5 \%$ & $71.6 \%$ & $39.6 \%$ & $41.3 \%$ & $25.0 \%$ & $52.9 \%$ & $51.0 \%$ \\
\hline Full loaf of white bread & 62 & 60 & 58 & 19 & 27 & 17 & 12 & 193 \\
\hline & $12.2 \%$ & $40.3 \%$ & $24.6 \%$ & $39.6 \%$ & $58.7 \%$ & $60.7 \%$ & $35.3 \%$ & $35.7 \%$ \\
\hline $250 \mathrm{~g}$ sugar & 338 & 134 & 197 & 44 & 42 & 23 & 22 & 462 \\
\hline & $66.3 \%$ & $89.9 \%$ & $83.5 \%$ & $91.7 \%$ & $91.3 \%$ & $82.1 \%$ & $64.7 \%$ & $85.4 \%$ \\
\hline $500 \mathrm{~g}$ sugar & 408 & 137 & 217 & 47 & 44 & 26 & 25 & 496 \\
\hline & $80.0 \%$ & $91.9 \%$ & $91.9 \%$ & $97.9 \%$ & $95.7 \%$ & $92.9 \%$ & $73.5 \%$ & $91.7 \%$ \\
\hline $340 \mathrm{ml}$ Coke & 220 & 94 & 134 & 9 & 43 & 6 & 13 & 299 \\
\hline & $43.1 \%$ & $63.1 \%$ & $56.8 \%$ & $18.8 \%$ & $93.5 \%$ & $21.4 \%$ & $38.2 \%$ & $55.3 \%$ \\
\hline 1.5 litre Coke & 233 & 37 & 203 & 5 & 8 & 4 & 22 & 279 \\
\hline & $45.7 \%$ & $24.8 \%$ & $86.0 \%$ & $10.4 \%$ & $17.4 \%$ & $14.3 \%$ & $64.7 \%$ & $51.6 \%$ \\
\hline Jive & 81 & 31 & 122 & 2 & 7 & 3 & 14 & 179 \\
\hline & $15.9 \%$ & $20.8 \%$ & $51.7 \%$ & $4.2 \%$ & $15.2 \%$ & $10.7 \%$ & $41.2 \%$ & $33.1 \%$ \\
\hline Double 0 & 80 & 13 & 106 & 4 & 6 & 2 & 12 & 143 \\
\hline & $15.7 \%$ & $8.7 \%$ & $44.9 \%$ & $8.3 \%$ & $13.0 \%$ & $7.1 \%$ & $35.3 \%$ & $26.4 \%$ \\
\hline Premium cigarette & 419 & 139 & 210 & 43 & 44 & 25 & 24 & 485 \\
\hline & $82.2 \%$ & $93.3 \%$ & $89.0 \%$ & $89.6 \%$ & $95.7 \%$ & $89.3 \%$ & $70.6 \%$ & $89.6 \%$ \\
\hline Economic cigarette & 166 & 65 & 148 & 27 & 21 & 14 & 9 & 284 \\
\hline & $32.5 \%$ & $43.6 \%$ & $62.7 \%$ & $56.3 \%$ & $45.7 \%$ & $50.0 \%$ & $26.5 \%$ & $52.5 \%$ \\
\hline Average & $48.7 \%$ & $55.0 \%$ & $70.4 \%$ & $48.3 \%$ & $61.2 \%$ & $47.9 \%$ & $52.4 \%$ & $61.1 \%$ \\
\hline
\end{tabular}


Table 5: Mean price per product by location (in cents, 2013 prices).

\begin{tabular}{|c|c|c|c|c|c|c|}
\hline \multirow[b]{2}{*}{1 litre milk } & \multirow{2}{*}{$\begin{array}{c}\text { Cape Town [I] } \\
\text { [I] - [II] }\end{array}$} & \multirow{2}{*}{$\begin{array}{c}\begin{array}{c}\text { Durban [II] } \\
\text { [I] - [III] }\end{array} \\
1230.23\end{array}$} & \multirow{2}{*}{$\begin{array}{c}\begin{array}{c}\text { Gauteng [III] } \\
\text { [II] - [III] }\end{array} \\
1181.93\end{array}$} & \multicolumn{3}{|c|}{ Mean difference } \\
\hline & & & & $-529.78^{*}$ & $-481.48^{\#}$ & 48.30 \\
\hline 6 eggs & 675.83 & 958.92 & 651.17 & $-283.08^{*}$ & $24.66^{\#}$ & $307.74 \wedge$ \\
\hline Half loaf of white bread & 434.74 & 516.41 & 523.30 & $-81.68^{*}$ & $-88.56^{\#}$ & -6.89 \\
\hline Full loaf of white bread & 738.71 & 683.90 & 642.15 & 54.81 & $96.56^{\#}$ & 41.75 \\
\hline $250 \mathrm{~g}$ sugar & 369.61 & 490.17 & 399.11 & $-120.55^{*}$ & $-29.50^{\#}$ & $91.06^{\wedge}$ \\
\hline $500 \mathrm{~g}$ sugar & 611.07 & 774.22 & 663.21 & $-163.16^{*}$ & $-52.14^{\#}$ & $111.02^{\wedge}$ \\
\hline $340 \mathrm{ml}$ Coke & 670.78 & 778.58 & 720.05 & $-107.80^{*}$ & $-49.28^{\#}$ & $58.52^{\wedge}$ \\
\hline 1.5 litre Coke & 1071.01 & $N / A^{a}$ & 1048.46 & $N / A^{a}$ & 22.56 & $\mathrm{~N} / \mathrm{A}^{\mathrm{a}}$ \\
\hline Jive & 1106.20 & $\mathrm{~N} / \mathrm{A}^{\mathrm{a}}$ & 1203.69 & $N / A^{a}$ & -97.49 & $N / A^{a}$ \\
\hline Double 0 & 1094.91 & $\mathrm{~N} / \mathrm{A}^{\mathrm{a}}$ & $N / A^{a}$ & $\mathrm{~N} / \mathrm{A}^{\mathrm{a}}$ & $N / A^{a}$ & $\mathrm{~N} / \mathrm{A}^{\mathrm{a}}$ \\
\hline Premium cigarette & 163.58 & 222.40 & 196.32 & $-58.82^{*}$ & $-32.75^{\#}$ & $26.07 \wedge$ \\
\hline Economic cigarette & 58.43 & 108.74 & 55.49 & $-50.31^{*}$ & 2.94 & $53.25^{\wedge}$ \\
\hline
\end{tabular}

Notes: ${ }^{\text {a }}$ /A indicates not applicable as product was not sold in that site. None of the Spaza shops from Durban in the sample reported to have 1.5 I Coke, Jive and Double 0 in stock, while none of the Spaza shops from Gauteng in the sample reported to have Double 0 in stock, at the time of the survey.

*Difference between the mean Cape Town price and mean Durban price is statistically significant at alpha $=5 \%$.

"Difference between the mean Cape Town price and mean Gauteng price is statistically significant at alpha $=5 \%$.

${ }^{\wedge}$ Difference between the mean Durban price and mean Gauteng price is statistically significant at alpha $=5 \%$.

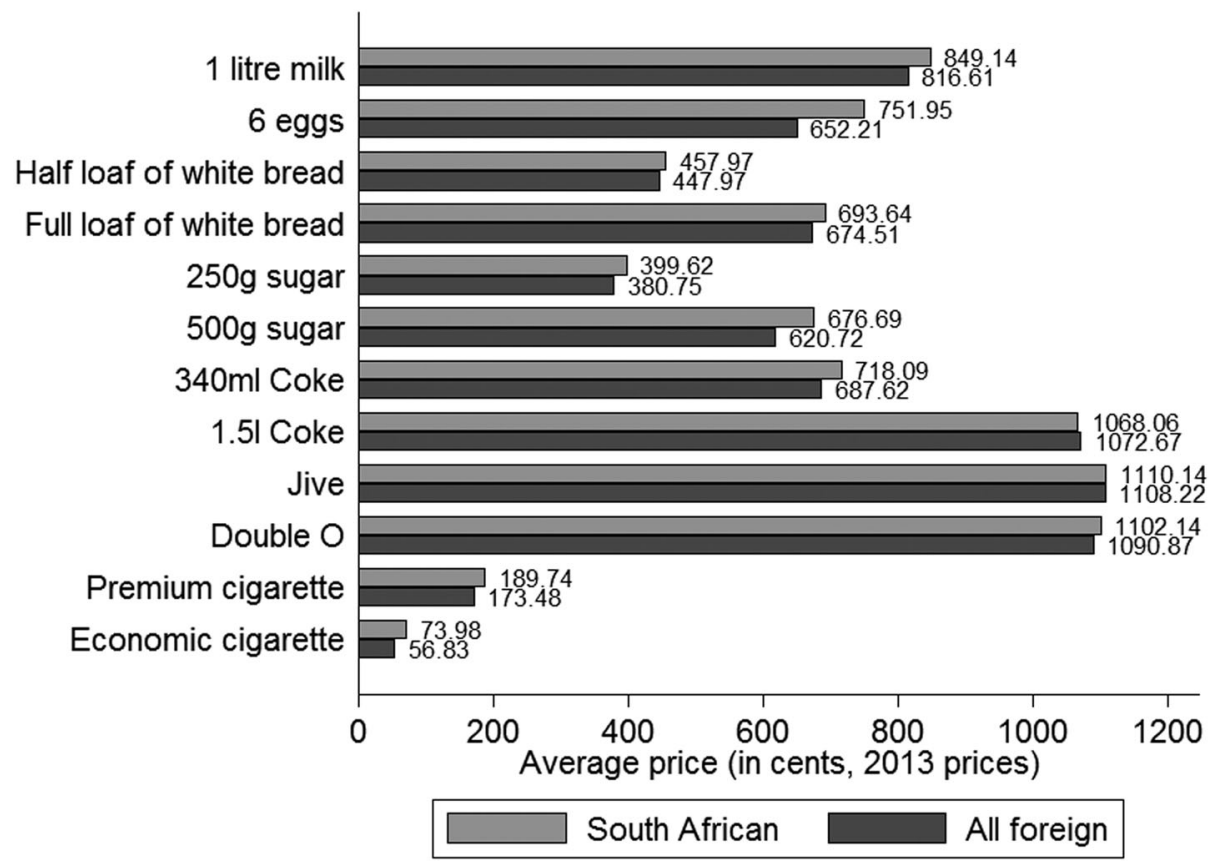

Figure 3: Average price per product, South African versus foreign (in cents, 2013 prices).

significantly higher in the former location, most notably eggs (slightly more than R3 more expensive in Durban).

\subsection{Price and nationality}

At the centre of the claim that foreign shopkeepers outcompete South Africans is the idea of price competition, specifically the claim that foreign shopkeepers as a whole have lower 
Table 6: Foreign mean price per product minus South African mean price per product (in cents, 2013 prices).

\begin{tabular}{|c|c|c|c|c|c|c|c|}
\hline & Ethiopian & Somalian & Mozambiquan & Bangladeshi & Zimbabwean & Other & $\begin{array}{c}\text { All } \\
\text { foreign }\end{array}$ \\
\hline 1 litre milk & $183.74^{*}$ & $-172.80^{*}$ & 180.38 & $183.05^{*}$ & 222.68 & $-134.47^{*}$ & -32.53 \\
\hline 6 eggs & $-98.44^{*}$ & $-95.79^{*}$ & $-113.02^{*}$ & $-111.04^{*}$ & $-95.26^{*}$ & $-101.59^{*}$ & $-99.75^{*}$ \\
\hline $\begin{array}{l}\text { Half loaf of white } \\
\text { bread }\end{array}$ & 21.13 & $-27.90^{*}$ & $60.89 *$ & 16.13 & 62.92 & $-48.73^{*}$ & -9.99 \\
\hline $\begin{array}{l}\text { Full loaf of white } \\
\text { bread }\end{array}$ & -26.17 & 34.20 & $-87.33^{*}$ & -65.57 & -70.61 & 43.53 & -19.14 \\
\hline $250 \mathrm{~g}$ sugar & -8.91 & $-29.19^{*}$ & 9.42 & $-37.24^{*}$ & -3.43 & -24.69 & $-18.87^{*}$ \\
\hline $500 \mathrm{~g}$ sugar & $-54.85^{*}$ & $-78.92^{*}$ & -2.51 & $-46.59^{*}$ & 16.79 & $-55.52^{*}$ & $-55.97^{*}$ \\
\hline $340 \mathrm{ml}$ Coke & -21.53 & $-47.90^{*}$ & 40.99 & -5.54 & -50.66 & -37.93 & $-30.47^{*}$ \\
\hline 1.5 litre Coke & 42.19 & 0.35 & 5.20 & -55.26 & -7.32 & 4.62 & 4.61 \\
\hline Jive & 30.46 & -5.92 & 6.43 & -51.57 & 21.92 & -20.20 & -1.92 \\
\hline Double 0 & $0.75^{*}$ & -12.36 & $14.43^{*}$ & -17.34 & $14.43^{*}$ & -24.47 & -11.27 \\
\hline Premium cigarette & $-12.98^{*}$ & $-29.03^{*}$ & $8.49^{*}$ & -8.17 & $17.76^{*}$ & $-18.08^{*}$ & $-16.26^{*}$ \\
\hline $\begin{array}{l}\text { Economic } \\
\text { cigarette }\end{array}$ & $-13.65^{*}$ & $-17.68^{*}$ & -19.76 & -17.51 & $-20.24^{*}$ & $-20.38^{*}$ & $-17.15^{*}$ \\
\hline Total & 41.74 & -482.94 & 108.98 & -216.65 & 103.61 & -437.91 & -308.70 \\
\hline
\end{tabular}

Note: *Difference between the mean South African price and mean foreign price is statistically significant at alpha $=5 \%$.

prices than South African. This is somewhat confirmed by Figure 3, where foreign prices are slightly cheaper than South African, with the exception of 1.5 litre Coke. In addition, the last column of Table 6 shows that the foreign prices are significantly cheaper than the South African prices on average only for six products (eggs, $250 \mathrm{~g}$ sugar, $500 \mathrm{~g}$ sugar, $340 \mathrm{ml}$ Coke, premium cigarettes and economic cigarettes).

However, once one disaggregates this by product and nationality, the contrast breaks down. Hence, as can be seen from Table 6, only for eggs and economy cigarettes are all foreign traders cheaper on mean price than South Africans, but South Africans are cheaper for 1 litre milk and full loaf of white bread than almost all other nationalities. Perhaps more tellingly, however, out of the total of 72 per-product mean price differences in the table, the foreign prices are cheaper in 47 of them (i.e. negative mean price differences). Nonetheless, only 25 of these 47 differences are statistically significant. In contrast, significant positive price differences (i.e. foreign prices are more expensive on average) are found eight times in total in the table, most notably milk (being 183.74 and 183.05 cents higher in Ethiopian and Bangladeshi shops respectively, compared with South African shops).

This claim is confirmed by Figure 4 that compares the mean price per product between South African shopkeepers and those of other nationalities. Here the difference in mean price on a basket of goods is significant, with Somalis the cheapest by nearly R5. Critically, however, South Africans are mid-table, with only Somali, Bangladeshi and other smaller nationalities being cheaper. Somewhat remarkably given the common discourse, Ethiopian Spaza shopkeepers are nearly 42 cents more expensive over a basket of goods, with Mozambicans and Zimbabwean at the bottom of the list at over R1 costlier per basket.

This picture is confirmed by a comparison of the difference between South African and other nationalities on median price per product, as presented in Table 7. Indeed, if one removes 1 litre milk and the full loaf of white bread from the comparison, the remaining median price differences are almost all less than 50 cents. 


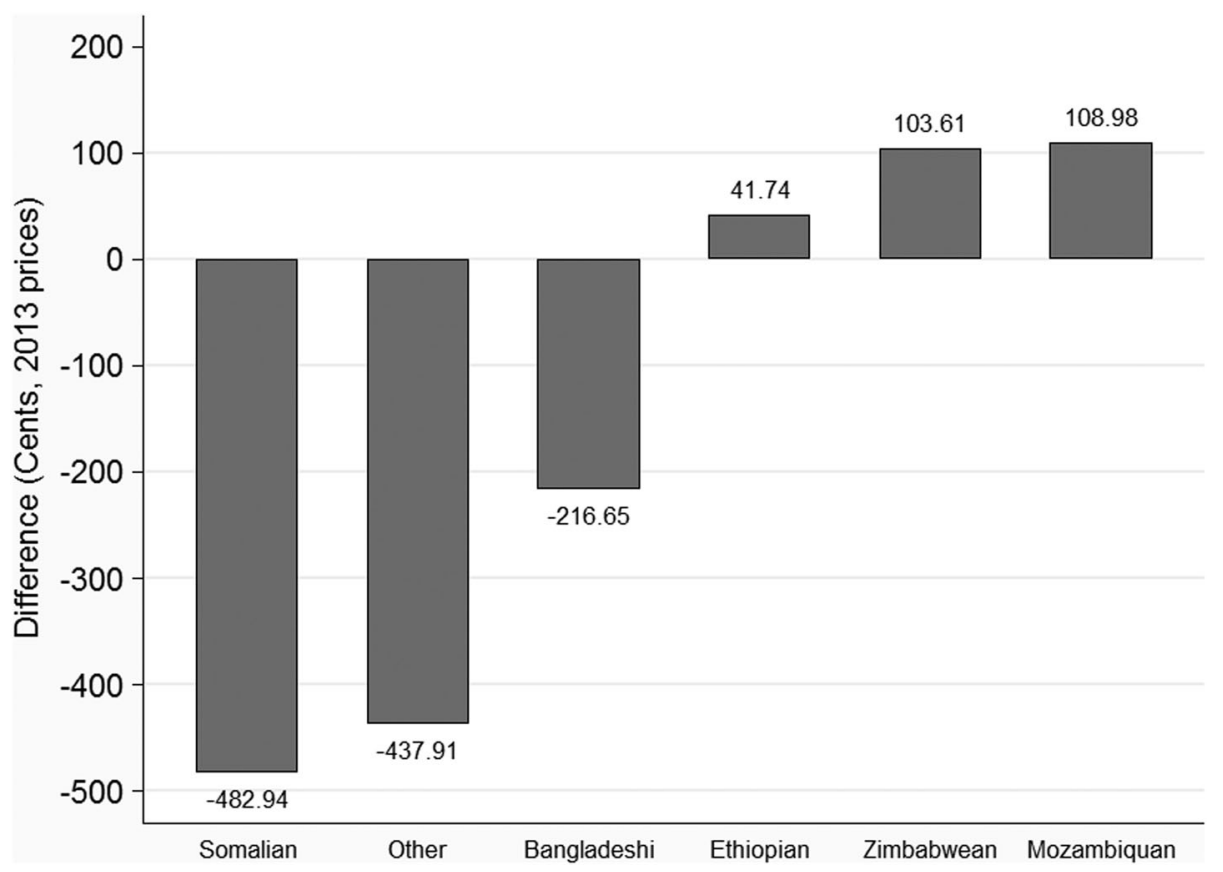

Figure 4: Total difference in mean price on basket of goods, South African vs other nationality (in cents, 2013 prices).

Table 7: Median foreign price per product minus median South African price per product (in cents, 2013 prices).

\begin{tabular}{lrrrrrr}
\hline & Ethiopian & Somalian & Mozambiquan & Bangladeshi & Zimbabwean & Other \\
\hline 1 litre milk & 429.32 & -37.25 & 285.67 & 412.75 & 512.75 & -17.31 \\
6 eggs & -35.56 & 0.00 & -35.56 & -35.56 & 0.00 & 0.00 \\
Half loaf of white bread & 0.00 & 0.00 & 60.88 & 29.16 & 53.37 & -51.23 \\
Full loaf of white bread & -105.73 & 52.87 & -105.73 & -128.96 & -128.96 & 45.69 \\
$250 \mathrm{~g}$ sugar & 0.00 & -20.74 & 9.20 & -20.74 & 0.00 & -30.77 \\
$500 \mathrm{~g}$ sugar & -55.83 & -88.42 & -35.56 & -35.56 & -9.97 & -55.83 \\
$340 \mathrm{ml}$ Coke & -25.77 & -55.83 & 14.34 & 0.00 & -27.91 & -55.83 \\
1.5 litre Coke & 0.00 & -55.83 & 0.00 & -85.70 & -55.83 & -29.63 \\
Jive & 0.00 & 0.00 & 0.00 & -59.26 & 0.00 & -29.63 \\
Double O & 0.00 & 0.00 & 0.00 & -59.26 & 0.00 & 0.00 \\
Premium cigarette & -2.51 & -2.51 & 41.46 & -2.51 & 41.46 & -2.51 \\
Economic cigarette & 0.00 & 0.00 & -2.96 & 0.00 & 0.00 & -2.96 \\
\hline
\end{tabular}

Note: It is only possible to test whether the foreign price is statistically significant from the South African price at the mean, but not at the median.

\subsection{Price and spatiality}

Notably, however, the analysis of price by location and nationality separately across the whole sample tells only part of the story. When one unpacks price by nationality according to the three cities, then the contrast between South African and foreign traders grows - at least in Durban and Johannesburg. Thus as presented in Table 8, in Cape Town both Ethiopian and Mozambican traders are slightly more expensive across a basket of goods than South Africans, and Zimbabweans are very slightly cheaper. Notably only Somali traders are substantially cheaper at an average of R4.40 for 12 products. Given that 
Table 8: Different in cents on the basket of goods by area (mean foreign price - mean South African price).

\begin{tabular}{lccc}
\hline & Cape Town & Johannesburg & Durban \\
\hline Bangladesh & -438.99 & -321.00 & N/A \\
Ethiopian & 99.52 & -337.84 & -550.90 \\
Mozambiquan & 8.73 & -193.07 & N/A \\
Somalian & -205.40 & -205.83 & -526.96 \\
Zimbabwean & -17.33 & -194.14 & N/A \\
Other & -193.46 & 117.29 & N/A \\
\hline
\end{tabular}

Note: N/A = impossible to derive the mean price difference, since these four 'foreign' Spaza shops do not exist in Durban in the sample.

Somali traders constitute some 220 of the 575 shops in the Cape Town sample, or $38 \%$, with South African constituting 277 or $48 \%$, it is easy to see how the people come to believe the claim that foreign traders are cheaper than South African, when the reality is more diverse and complex.

In Durban, as presented in Table 8, our data reveal that foreign traders are substantially cheaper than South African. However, given that the numbers are very small, with foreign traders constituting just 14 of 126 shops in KwaMashu, it seems prudent not to read too much into these findings for now. Lastly, in Johannesburg, as also presented in Table 8, South African Spaza shopkeepers are more expensive than almost all other foreign traders, other than the six foreign nationals in the 'other category', although not dramatically so. In short, difference in mean price by nationality appears to differ significantly by place, such that the claim that foreigner shopkeepers are cheaper than South African holds for Johannesburg in a way it does not for Cape Town.

\subsection{Price and product}

The analysis so far has proceeded with prices controlled for inflation. However, as revealed by Table 9, nationality appears to matter less than place when it comes to the price of certain products. First, Double $\mathrm{O}$ was a product only found in Cape Town and not

Table 9: Johannesburg mean price by nationality - Cape Town mean price by nationality (in cents, 2013 prices).

\begin{tabular}{|c|c|c|c|c|c|c|c|}
\hline & $\begin{array}{c}\text { South } \\
\text { African }\end{array}$ & Ethiopian & Somalian & Mozambiquan & Bangladeshi & Zimbabwean & Other \\
\hline 1 litre milk & 510.00 & 351.24 & 563.23 & 454.63 & 580.74 & 516.71 & 423.04 \\
\hline 6 eggs & -20.63 & -41.12 & 10.06 & -33.89 & -2.87 & -15.06 & 1.98 \\
\hline $\begin{array}{l}\text { Half loaf of white } \\
\text { bread }\end{array}$ & 85.54 & 90.47 & 55.60 & 73.80 & 82.26 & 103.96 & 151.01 \\
\hline $\begin{array}{l}\text { Full loaf of white } \\
\text { bread }\end{array}$ & -69.23 & -139.59 & -120.20 & N/A & -86.39 & $\mathrm{~N} / \mathrm{A}$ & 292.08 \\
\hline $250 \mathrm{~g}$ sugar & 49.74 & 13.96 & 27.22 & 50.77 & 10.85 & 6.20 & -13.25 \\
\hline $500 \mathrm{~g}$ sugar & 76.94 & -11.13 & 80.42 & 80.91 & 73.19 & 47.64 & 41.95 \\
\hline $340 \mathrm{ml}$ Coke & 55.28 & 41.79 & 68.57 & 78.71 & 76.53 & -3.01 & 95.37 \\
\hline 1.5 I Coke & 49.65 & 19.46 & -63.80 & -216.57 & -186.05 & -74.44 & N/A \\
\hline Jive & 156.20 & N/A & $\mathrm{N} / \mathrm{A}$ & N/A & 77.76 & 46.47 & $\mathrm{~N} / \mathrm{A}$ \\
\hline Double 0 & N/A & N/A & N/A & N/A & N/A & N/A & $\mathrm{N} / \mathrm{A}$ \\
\hline Premium cigarette & 45.11 & 13.05 & 30.90 & 33.90 & 25.36 & 49.69 & 34.39 \\
\hline $\begin{array}{l}\text { Economic } \\
\text { cigarette }\end{array}$ & -5.85 & -2.89 & -2.56 & -6.00 & 1.89 & -2.25 & 2.87 \\
\hline
\end{tabular}

Note: N/A means not applicable as these nationalities of shop keeper were not found in the survey. 
outside the province. Second, the most expensive milk in Cape Town is still cheaper than the cheapest milk in Johannesburg. Conversely, the most expensive full loaf of white bread in Johannesburg was less than the cheapest price in Cape Town. Hence, for these products, there are reasons other than those linked to nationality that have a more profound impact on price. These reasons are probably linked to the spatial particularities of the supply chain for each product, such as the costs of transporting milk to the high veld for example. Indeed, a similar point applies to 1.5 litre Coke where South African Spaza shopkeepers are able to outcompete foreign traders in price because Coke delivers directly to township Spazas and not through wholesalers.

\subsection{Further analysis}

In addition to asking the Spaza shopkeepers the selling prices of the goods, they were also asked to report their demographic and work characteristics. The results are summarised in Table A1 in Appendix A (one drawback is the high non-response rate for some questions), and some of them are discussed here. First, a very high proportion of the foreign shopkeepers (85\%) are males, but this share is only just above $50 \%$ for the South Africans. Moreover, the foreign shopkeepers are relatively younger, as a higher proportion of them (nearly $38 \%$, compared with only a quarter in the case of South Africans) were aged below 35 years at the time of the survey.

Approximately half of the foreigners (52.2\%) have been operating their Spaza shop businesses for one year or less at the time of the survey, but this proportion is only about a quarter $(23.7 \%)$ for the South African shopkeepers. In other words, the South African-owned Spaza shops are associated with longer tenure. Finally, 56.5\% of premises are owned by the South Africans, but this figure is only $5.2 \%$ in the case of foreign operators.

This section concludes by presenting the results of the ordinary least squares multivariate regressions on the real selling price (in cents, 2013 prices) in log terms of each good, as presented in Table 10. The explanatory variables include province (reference group: Durban); nationality (reference group: South African); gender (reference group: male); age in years and age in years squared; structure of the business (reference group: brick building); time in business in years; number of workers (including the owner) in the business (reference group: one worker); and ownership of the premise (reference group: owned). Before the main highlights of the multivariate analysis are discussed, the results should be interpreted with caution due to the high non-response rate for some of the explanatory variables (refer to Table A1 in Appendix A).

From Table 10 it can be seen that the Cape Town dummy variable has a negative sign and is statistically significant in nine regressions. The same finding is observed for the Gauteng dummy in eight regressions. These results confirm the findings presented in Table 5 that the goods are significantly cheaper in general in these two locations, compared with Durban. In contrast, the results on the nationality dummy variables are mixed; some of the statistically significant results are associated with negative coefficients while others are associated with positive coefficients. This implies that there is no clear indication that the foreign Spaza shops always outcompete the South African shops by selling goods at significantly lower prices, as already found throughout Section 3. 
Table 10: Ordinary least squares regressions on log real price (in cents, 2013 prices).

\begin{tabular}{|c|c|c|c|c|c|c|}
\hline & 1 litre milk & 6 eggs & Half loaf of bread & Full loaf of bread & 250 g sugar & 500 g sugar \\
\hline Province: Cape Town & $-0.494^{* * *}$ & $-0.253^{* * *}$ & -0.055 & 0.116 & $-0.191^{* * *}$ & $-0.151^{* * *}$ \\
\hline Province: Gauteng & $-0.096^{* *}$ & $-0.312^{* * *}$ & 0.017 & $-0.175^{*}$ & $-0.184^{* * *}$ & $-0.152^{* * *}$ \\
\hline Nationality: Ethiopian & 0.110 & -0.022 & $-0.088^{* *}$ & 0.076 & 0.015 & -0.023 \\
\hline Nationality: Somalian & -0.036 & 0.043 & 0.069 & 0.316 & -0.091 & 0.018 \\
\hline Nationality: Mozambiquan & 0.053 & 0.033 & $\mathrm{~N} / \mathrm{A}$ & $\mathrm{N} / \mathrm{A}$ & -0.071 & 0.046 \\
\hline Nationality: Bangladeshi & -0.024 & 0.001 & 0.038 & 0.006 & 0.042 & $0.044^{* *}$ \\
\hline Nationality: Zimbabwean & 0.050 & 0.013 & -0.107 & $\mathrm{~N} / \mathrm{A}$ & $0.165^{* *}$ & $0.154^{* *}$ \\
\hline Nationality: other & $0.069^{* * *}$ & $0.046^{* * *}$ & $0.031^{* *}$ & $0.080^{* * *}$ & 0.017 & $0.043^{* * *}$ \\
\hline Gender: female & 0.004 & 0.012 & -0.017 & $-0.063^{* *}$ & 0.014 & 0.014 \\
\hline Gender: unspecified & 0.010 & $-0.045^{* *}$ & -0.025 & -0.004 & $-0.088^{* * *}$ & -0.020 \\
\hline Age in years & 0.003 & $0.006^{* *}$ & 0.002 & $-0.017^{* *}$ & -0.001 & 0.000 \\
\hline Age in years squared & 0.000 & $0.000^{* *}$ & 0.000 & $0.000^{* *}$ & 0.000 & 0.000 \\
\hline Dummy: unspecified age & 0.005 & $0.107^{* *}$ & -0.016 & $-0.319^{* * *}$ & -0.070 & -0.033 \\
\hline Structure: formal house & 0.016 & $0.026^{* * *}$ & $0.035^{* *}$ & $0.232^{* * *}$ & 0.005 & -0.008 \\
\hline Structure: Wendy house & $0.058^{* * *}$ & $0.019 *$ & $0.025^{*}$ & 0.025 & $0.028^{*}$ & 0.008 \\
\hline Structure: other & $0.050^{*}$ & $0.032^{* *}$ & $0.042^{* *}$ & 0.016 & 0.033 & 0.007 \\
\hline Structure: unspecified & $-0.067^{* *}$ & $0.040^{* *}$ & 0.031 & 0.018 & 0.004 & -0.023 \\
\hline Time in business in years & -0.003 & 0.000 & 0.002 & 0.002 & 0.000 & 0.000 \\
\hline Dummy: time in business unspecified & 0.010 & -0.005 & $-0.039^{*}$ & 0.010 & 0.016 & -0.009 \\
\hline Number of workers: two & -0.007 & 0.000 & -0.006 & 0.021 & 0.002 & $-0.044^{* * *}$ \\
\hline Number of workers: three or more & 0.004 & 0.005 & -0.040 & 0.004 & -0.007 & $-0.039 * *$ \\
\hline Number of workers: unspecified & $-0.095^{* *}$ & -0.014 & -0.053 & -0.024 & -0.002 & $-0.060^{* * *}$ \\
\hline Ownership: rented & $-0.059 * * *$ & $-0.029^{* * *}$ & -0.016 & $0.103^{* * *}$ & -0.029 & $-0.032^{* *}$ \\
\hline Ownership: unspecified & $-0.148^{* * *}$ & $-0.050^{* * *}$ & $-0.036^{* * *}$ & 0.041 & $-0.058^{* * *}$ & $-0.062^{* * *}$ \\
\hline Constant & $7.146^{* * *}$ & $6.662^{* * *}$ & $6.187^{* * *}$ & $6.699^{* * *}$ & $6.179 * * *$ & $6.669^{* * *}$ \\
\hline Sample size & 655 & 928 & 536 & 255 & 800 & 904 \\
\hline $\mathrm{R}^{2}$ & 0.7362 & 0.6048 & 0.3971 & 0.5118 & 0.2746 & 0.3518 \\
\hline Adjusted $\mathrm{R}^{2}$ & 0.7262 & 0.5943 & 0.3700 & 0.4656 & 0.2522 & 0.3341 \\
\hline F-statistic & 73.26 & 57.58 & 14.66 & 11.06 & 12.23 & 19.88 \\
\hline \multirow[t]{2}{*}{ Prob. $>\mathrm{F}$} & 0.0000 & 0.0000 & 0.0000 & 0.0000 & 0.0000 & 0.0000 \\
\hline & $340 \mathrm{ml}$ Coke & 1.5 litre Coke & Jive & Double 0 & Premium cigarette & Economic cigarette \\
\hline Province: Cape Town & $-0.082^{* * *}$ & $0.092^{* *}$ & $-0.140^{* * *}$ & N/A & $-0.250^{* * *}$ & $-0.358^{* * *}$ \\
\hline Province: Gauteng & $-0.068^{* * *}$ & $\mathrm{~N} / \mathrm{A}$ & $\mathrm{N} / \mathrm{A}$ & $\mathrm{N} / \mathrm{A}$ & $-0.084^{* * *}$ & $-0.476^{* * *}$ \\
\hline Nationality: Ethiopian & 0.018 & -0.008 & -0.019 & -0.024 & 0.016 & -0.056 \\
\hline Nationality: Somalian & 0.081 & $\mathrm{~N} / \mathrm{A}$ & N/A & $\mathrm{N} / \mathrm{A}$ & $0.158^{* *}$ & -0.032 \\
\hline
\end{tabular}


Table 10: Continued.

\begin{tabular}{|c|c|c|c|c|c|c|}
\hline & 1 litre milk & 6 eggs & Half loaf of bread & Full loaf of bread & $250 \mathrm{~g}$ sugar & $500 \mathrm{~g}$ sugar \\
\hline Nationality: Mozambiquan & $\mathrm{N} / \mathrm{A}$ & 0.020 & 0.017 & $\mathrm{~N} / \mathrm{A}$ & 0.033 & -0.033 \\
\hline Nationality: Bangladeshi & $0.095^{* * *}$ & 0.011 & 0.037 & 0.018 & $0.041^{* *}$ & -0.003 \\
\hline Nationality: Zimbabwean & -0.043 & 0.063 & $-0.113^{*}$ & $\mathrm{~N} / \mathrm{A}$ & $0.133^{* *}$ & $\mathrm{~N} / \mathrm{A}$ \\
\hline Nationality: other & $0.022^{*}$ & 0.014 & $0.034^{* * *}$ & $0.029^{* * *}$ & $0.042^{* * *}$ & $0.062^{* * *}$ \\
\hline Gender: female & -0.017 & -0.013 & $-0.039 * * *$ & -0.013 & 0.009 & -0.003 \\
\hline Gender: unspecified & $-0.062^{* * *}$ & $0.030^{*}$ & -0.029 & 0.006 & $-0.046^{* *}$ & $-0.120^{*}$ \\
\hline Age in years & $0.012^{* * *}$ & -0.003 & $-0.025^{* * *}$ & $\mathrm{~N} / \mathrm{A}$ & 0.001 & 0.009 \\
\hline Age in years squared & $0.000^{* * *}$ & 0.000 & $0.000^{* * *}$ & 0.000 & 0.000 & 0.000 \\
\hline Dummy: unspecified age & $0.191^{* * *}$ & -0.070 & $-0.409 * * *$ & $\mathrm{~N} / \mathrm{A}$ & 0.007 & 0.033 \\
\hline Structure: formal house & 0.005 & $0.051^{* * *}$ & $0.032^{* *}$ & $0.034^{* * *}$ & -0.001 & -0.002 \\
\hline Structure: Wendy house & 0.002 & $0.059^{* * *}$ & $0.028^{* *}$ & $0.039^{* * *}$ & $0.031^{* * *}$ & 0.028 \\
\hline Structure: other & -0.002 & $0.051^{* * *}$ & $0.052^{* * *}$ & 0.017 & 0.009 & $-0.071^{* *}$ \\
\hline Structure: unspecified & -0.011 & $-0.060^{* * *}$ & 0.004 & -0.002 & 0.000 & 0.045 \\
\hline Time in business in years & 0.001 & -0.001 & 0.000 & -0.002 & 0.001 & 0.000 \\
\hline Dummy: time in business unspecified & 0.022 & -0.013 & -0.009 & -0.003 & -0.003 & 0.010 \\
\hline Number of workers: two & $0.026^{*}$ & $-0.146^{* * *}$ & $0.220^{* * *}$ & -0.014 & $-0.037^{* * *}$ & $0.058^{* *}$ \\
\hline Number of workers: three or more & 0.005 & $-0.187^{* * *}$ & $0.253^{* * *}$ & $\mathrm{~N} / \mathrm{A}$ & $-0.036^{* *}$ & 0.058 \\
\hline Number of workers: unspecified & 0.017 & $-0.177^{* * *}$ & $0.251^{* * *}$ & $\mathrm{~N} / \mathrm{A}$ & -0.007 & $0.075^{*}$ \\
\hline Ownership: rented & -0.017 & 0.019 & 0.021 & $0.065^{* * *}$ & $-0.033^{* * *}$ & $-0.156^{* * *}$ \\
\hline Ownership: unspecified & $-0.048^{* * *}$ & 0.009 & 0.008 & $0.046^{* * *}$ & $-0.046^{* * *}$ & $-0.154^{* * *}$ \\
\hline Constant & $6.403^{* * *}$ & $7.089^{* * *}$ & $7.264^{* * *}$ & $6.928^{* * *}$ & $5.346^{* * *}$ & $4.428^{* * *}$ \\
\hline Sample size & 519 & 512 & 260 & 223 & 904 & 450 \\
\hline$R^{2}$ & 0.3808 & 0.3006 & 0.2864 & 0.1698 & 0.5501 & 0.6725 \\
\hline Adjusted $\mathrm{R}^{2}$ & 0.3520 & 0.2692 & 0.2202 & 0.1097 & 0.5378 & 0.6548 \\
\hline F-statistic & 13.24 & 9.55 & 4.32 & 2.82 & 44.79 & 38.03 \\
\hline Prob. $>\mathrm{F}$ & 0.0000 & 0.0000 & 0.0000 & 0.0000 & 0.0000 & 0.0000 \\
\hline
\end{tabular}

Notes: ${ }^{* *}$ Significant at $1 \% .{ }^{* *}$ Significant at $5 \%$. ${ }^{*}$ Significant at $1 \%$.

$\mathrm{N} / \mathrm{A}=$ explanatory variable is omitted due to perfect collinearity. 
Looking at the demographic variables, the female dummy has a negative sign and is statistically significant in only two regressions (full loaf of bread and Jive), while the age variables have significant impact on prices in four regressions (6 eggs, full loaf of bread, $340 \mathrm{ml}$ Coke, Jive). As far as the structure of the business is concerned, it is interesting that for those owners reporting to operate their businesses in houses (either formal or Wendy houses), there was a positive and significant impact on prices in all but three (full loaf of bread, $340 \mathrm{ml}$ Coke, premium cigarette) regressions.

On the other hand, the time spent in the business has no significant impact on prices. Furthermore, for those operators working in premises with more than one worker, the significant impact on price is positive for three goods (340 $\mathrm{ml}$ Coke, Jive, economic cigarette) but negative for other three goods (500 g sugar, 1.5 litre Coke, premium cigarette). Finally, it is interesting that for those claiming they rented the premises at the time of the survey, the general impact on price is negative (but only significant in five goods), except that there is a significant positive impact on two goods (full loaf of bread and Double O). While we do not know the reason for these variations, it is clear that they do not correlate simply with citizenship.

\section{Conclusion}

The evidence from the SLF surveys suggests the claim that 'foreign' Spaza shopkeepers are outcompeting 'South African' Spaza shopkeepers conceals as much as it reveals. Differences between the two groups clearly exist, but lumping prices together in these two categories alone misses other important dynamics that confound this simplistic claim. Firstly, while nationality is a factor in price differentiation, it is not captured by the labels of 'foreign' versus South African, as there are significant differences by nationality within the 'foreign' category. Hence, we demonstrate that, across the sample as a whole, there are substantial variations in prices that seem to follow national lines. Secondly, we also demonstrate that, on average, South Africans are better stocked and better priced than Mozambicans and Zimbabweans, although less well stocked and more expensive than Somalis and Bangladeshis. Thirdly, place clearly matters too, not only because we find different nationalities in different cities, but because of the different patterns of price competition. Hence, while in Johannesburg most nationalities outcompete South African Spaza shopkeepers on price, the same is not true in Cape Town. Lastly, there are clearly product-specific dynamics that impact on price more profoundly than the nationality of shopkeepers, such that milk is cheaper in Cape Town and bread is cheaper in Johannesburg, irrespective of the nationality of the Spaza shopkeeper. In short, while buying from a foreigner is often cheaper than buying from a South African, this is not guaranteed, because it matters which nationality one buys from, in which city and for what product.

These findings are important not because they offer a better explanation of price variation or competitiveness, but because they push back against the widely held view that all foreigners outcompete all South Africans in the Spaza sector on product price. This view is one commonly cited in the public realm, and forms part of a larger discourse that sees foreign migrants' economic success as coming at the expense of South Africans. Indeed, these views are often cited in xenophobic mobilisation against foreign residents in township and foreign-run Spaza shops are regular targets of these progroms. This article reveals that these gross generalisations are simply not accurate. 


\section{Disclosure statement}

No potential conflict of interest was reported by the authors.

\section{References}

Africa Unite, 2007. Masiphumelele small business survey - A study for the Department of the Premier. Provincial Government of the Western Cape, Cape Town.

Anderson, JH, 1998. The size, origins, and character of Mongolia's informal sector during the transition. Policy Research Working Paper 1916, World Bank, Washington, DC.

Bernabè, S, 2002. Informal employment in countries in transition: A conceptual framework. CASE paper 56, Centre for Analysis of Social Exclusion, London.

Blunch, NH, Canagarajah, S \& Raju, D, 2001. The informal sector revisited: A synthesis across space and time. World Bank Social Protection Paper No. 0119, World Bank, Washington, DC.

Charman, A \& Petersen, L, 2007. Informal economy study: Trade component. Micro economic development strategy. Research Report. Provincial Government of Western Cape, Cape Town.

Charman, A, Petersen, L \& Piper, L, 2012. From local survivalism to foreign entrepreneurship: The transformation of the spaza sector in Delft, Cape Town. Transformation: Critical Perspectives on Southern Africa 78, 47-73.

Charman, A, Petersen, L, Legg, T, Liedeman, R \& Piper, L, 2015. Small area census approach to measure the township informal economy in South Africa. Journal of Mixed Methods Research 1-23. doi:10.1177/1558689815572024.

Charman, A \& Piper, L, 2012. Xenophobia, criminality or violent entrepreneurship? Violence against Somali shopkeepers in Delft South, Cape Town, South Africa. South African Review of Sociology 43(3), 81-105.

Citrin, J, Green, DP, Muste, C \& Wong, C, 1997. Public opinion toward immigration reform: The role of economic motivations. The Journal of Politics 59, 858-81.

Crush, J, 2008. The perfect storm: The realities of xenophobia in South Africa. Southern Africa Migration Project (SAMP) Policy Series Paper 50. Southern Africa Migration Programme, Waterloo.

Department of the Premier Western Cape, 2007. Documenting and evaluation report: Masiphumelele conflict intervention, August 2006-March 2007. Provincial Government of the Western Cape, Cape Town.

Essop, H \& Yu, D, 2008a. The South African informal sector (1997-2006). Stellenbosch Economic Working Papers: 03/08. Stellenbosch University, Stellenbosch.

Essop, H \& Yu, D, 2008b. Alternative definitions of informal sector employment in South Africa. Stellenbosch Economic Working Papers: 21/08. Stellenbosch University, Stellenbosch.

Everett, D, 2011. Xenophobia, state and society in South Africa, 2008-2010. Politikon 38(1), 7-36.

Fields, GS, 1975. Rural-urban migration, urban unemployment and underemployment, and job search activity in LDCs. Journal of Development Economics 2, 165-87.

Gastrow, V \& Amit, R, 2013. Somalinomics: A case study on the economics of Somali trade in the Western Cape. ACMS Research Report 42. http://www.migration.org.za/uploads/docs/report42.pdf Accessed 16 August 2014.

Global Post, 2013. Not wanted: Somalis in South Africa. http://www.globalpost.com/dispatch/news/ regions/africa/south-africa/131115/not-wanted-somalis-south-africa Accessed 16 August 2014.

Henley, A, Arabsheibani, GR \& Carneiro, FG, 2009. On defining and measuring the informal sector: Evidence from Brazil. World Development 37(5), 992-1003.

ILO (International Labour Organisation), 2009. The informal economy in Africa: Promoting transition to formality: Challenges and strategies. International Labour Organisation, Geveva.

Kershoff, GJ, 1996. The informal sector in South Africa. BER Occasional Research Paper 1996/1, Bureau of Economic Research, Stellenbosch.

Kingdon, GG \& Knight, J, 2004. Unemployment in South Africa: The nature of the beast. World Development 32(3), 391-408. 
Neves, D \& Du Toit, A, 2012. Money and sociality in South Africa's informal economy. Africa 82 (1), 131-49.

Palmade, V \& Anayiotos, A, 2005. Rising informality. Policy for the Private Sector: Note 298. World Bank, Washington, DC.

Pedahzur, A \& Yishai, Y, 1999. Hatred by hated people: Xenophobia in Israel. Studies in Conflict \& Terrorism 22(2), 101-17.

Perry, GE, Maloney, WF, Arias, OS, Fajnzylber, P, Mason, AD \& Saavedra-Chanduvi, J, 2007. Informality: Exit and exclusion. World Bank, Washington, DC.

Semyonov, M, Raijman, R \& Yom-Tov, A, 2002. Labor market competition, perceived threat, and endorsement of economic discrimination against foreign workers in Israel. Social Problems 49 (3), 416-31.

SLF (Sustainable Livelihoods Foundation), 2011. The Informal Economy of Towship Spaza Shops. http://livelihoods.org.za/wp-content/uploads/2015/05/The-Informal-Economy-of-TownshipSpaza-Shops-.pdf Accessed 16 November 2015.

SLF (Sustainable Livelihoods Foundation), 2014. SLF Informal Economy Overview. http:// livelihoods.org.za/wp-content/uploads/2015/05/SLF-Informal-Economy-Overview-final.pdf Accessed 16 November 2015.

Somaliland Press, 2012. South Africa's xenophobia claims ten Somali traders in five days. http:// somalilandpress.com/south-africas-xenophobia-claims-ten-somali-traders-in-five-days-30612 Accessed 16 August 2014.

Weis, P. 1979. Nationality and statelessness in international law. Alphen aan den Rijn: Sijthoff \& Noordhoff.

Wimmer, A, 1997. Explaining xenophobia and racism: A critical review of current research approaches. Ethnic and Racial Studies 20(1), 17-41.

Zagefka, H, Brown, R, Broquard, M \& Martin, SL, 2007. Predictors and consequences of negative attitudes toward immigrants in Belgium and Turkey: The role of acculturation preferences and economic competition. British Journal of Social Psychology 46, 153-69. 


\section{Appendix A}

Table A1: Demographic and work characteristics of the respondents in the survey.

\begin{tabular}{|c|c|c|c|c|c|c|}
\hline & \multicolumn{2}{|c|}{ South Africa $(n=510)$} & \multicolumn{2}{|c|}{ Foreign $(n=541)$} & \multicolumn{2}{|c|}{ All $(n=1051)$} \\
\hline & $\mathbf{n}$ & $\%$ & $\mathbf{n}$ & $\%$ & $\mathbf{n}$ & $\%$ \\
\hline \multicolumn{7}{|l|}{ Gender } \\
\hline Male & 258 & 50.6 & 462 & 85.4 & 720 & 68.5 \\
\hline Female & 193 & 37.8 & 29 & 5.4 & 222 & 21.1 \\
\hline $\begin{array}{l}\text { Not specified } \\
\text { Aqe in years }\end{array}$ & 59 & 11.6 & 50 & 9.2 & 109 & 10.4 \\
\hline Below 25 years & 22 & 4.3 & 80 & 14.8 & 102 & 9.7 \\
\hline $25-34$ years & 59 & 11.6 & 124 & 22.9 & 183 & 17.4 \\
\hline $35-44$ years & 55 & 10.8 & 33 & 6.1 & 88 & 8.4 \\
\hline $45-54$ years & 55 & 10.8 & 3 & 0.6 & 58 & 5.5 \\
\hline 55 years or above & 31 & 6.1 & 3 & 0.6 & 34 & 3.2 \\
\hline Not specified & 288 & 56.5 & 298 & 55.1 & 586 & 55.8 \\
\hline \multicolumn{7}{|c|}{ Structure of Spaza business } \\
\hline Formal house & 87 & 17.1 & 103 & 19.0 & 190 & 18.1 \\
\hline Wendy house & 141 & 27.6 & 154 & 28.5 & 295 & 28.1 \\
\hline Brick building & 70 & 13.7 & 142 & 26.2 & 212 & 20.2 \\
\hline Other & 12 & 2.4 & 43 & 8.0 & 55 & 5.2 \\
\hline Not specified & 200 & 39.2 & 99 & 18.3 & 299 & 28.4 \\
\hline \multicolumn{7}{|c|}{ Time in business in years } \\
\hline Less than 1 year & 35 & 6.9 & 108 & 20.0 & 143 & 13.6 \\
\hline 1 year & 43 & 8.4 & 74 & 13.7 & 117 & 11.1 \\
\hline 2 years & 43 & 8.4 & 100 & 18.5 & 143 & 13.6 \\
\hline 3 years & 38 & 7.5 & 56 & 10.4 & 94 & 8.9 \\
\hline 4 years & 33 & 6.5 & 29 & 5.4 & 62 & 5.9 \\
\hline 5 years & 34 & 6.7 & 35 & 6.5 & 69 & 6.6 \\
\hline $6-10$ years & 101 & 19.8 & 37 & 6.8 & 138 & 13.1 \\
\hline More than 10 years & 90 & 17.6 & 11 & 2.0 & 101 & 9.6 \\
\hline Not specified & 93 & 18.2 & 91 & 16.8 & 184 & 17.5 \\
\hline \multicolumn{7}{|c|}{ Total number of workers (including owners) } \\
\hline 1 worker & 62 & 12.2 & 55 & 10.2 & 117 & 11.1 \\
\hline 2 workers & 66 & 12.9 & 136 & 25.1 & 202 & 19.2 \\
\hline 3 or more workers & 26 & 5.1 & 93 & 17.2 & 119 & 11.3 \\
\hline Not specified & 356 & 69.8 & 257 & 47.5 & 613 & 58.3 \\
\hline \multicolumn{7}{|c|}{ Ownership of premises } \\
\hline Owned & 288 & 56.5 & 28 & 5.2 & 316 & 30.1 \\
\hline Rented & 70 & 13.7 & 361 & 66.7 & 431 & 41.0 \\
\hline Not specified & 152 & 29.8 & 152 & 28.1 & 304 & 28.9 \\
\hline
\end{tabular}

